\title{
Morphological characterization of fruits and seeds of Ruellia furcata (Nees) Lindau (Acanthaceae) from Espírito Santo State, Brazil
}

\author{
Mariana Maciel Monteiro (iD) 1, Alexandre Indriunas (i] 2*, Elisa Mitsuko Aoyama (iD) 2 \\ ${ }^{1}$ Departamento de Botânica, Instituto de Biociências da Universidade de São Paulo (IB-USP). Rua do Matão, Tv. 14 - \\ Butantã, São Paulo - SP, 05508-090, Brasil. \\ ${ }_{2}^{2}$ Departamento de Ciências Agrárias e Biológicas, Centro Universitário Norte do Espírito Santo. Br 101 Norte, Km 60 - \\ Bairro Litorâneo, São Mateus - ES, 29932-900, Brasil. \\ *Corresponding author. E-mail: aleindri@gmail.com
}

\begin{abstract}
Acanthaceae is a wide spread family with usually capsular fruits, with two valves and explosive dehiscence containing two or more seeds. The morphological features of fruits and seeds are important in the identification at supra especific level, since they vary morphologically. Thus, this study aimed to characterize the morphology of the fruits and seeds of Ruellia furcata. This species is endemic to Brazil and restrict to restinga areas. The collection was carried out with the aid of a gauze type fabric. The fruits were measured in length of the sterile and fertile portion, total length, width, thickness, and retinacula height. The seeds were measured in length, width and thickness. For description, internal and external details were pointed. The fruits and seeds of $R$. furcata present morphological features that are commonly found in the genus however, its characteristics allow it to be positioned taxonomically and provide an understanding of its dispersion.
\end{abstract}

Keywords: Diaspores, Ruellinae, Trichomes

DOI: https://doi.org/10.33837/msj.v3i3.1265

Received July 5, 2020. Accepted December 3, 2020.

Associate editor: Ana Paula Silva Siqueira

\section{INTRODUCTION}

Acanthaceae present ca 190 genera and 4750 species (Daniel \& McDade, 2014) widely spread in tropical, subtropical and some temperate areas where they have little representation. In Brazil there are about 39 genera and 453 species at the forest formations mainly in the Southeast and Midwest (Profice et al., 2020). The family is represented by herbaceous plants, shrubs, trees, less often lianas (Judd et al., 2009). Considering the floral features, the great variety in color of petals is observed, which is related with attraction of pollinators (Abreu \&Vieira, 2004) as bees, wasps, butterflies, moths, and birds (Judd et al., 2009). This color variation gives the family an ornamental importance (Lorenzi \& Souza, 2008).

The fruits of Acanthaceae are usually capsular, with two valves and explosive dehiscence (Judd et al., 2009), with two or more seeds usually with persistent funicle (retinacula) or absent (Thunbergia Retz.) (Wasshausen \&Wood, 2004). However, capsular fruits are not the only type reported, drupes are also found

\section{Copyright (C) The Author(s).}

This is an open-access paper published by the Instituto Federal Goiano, Urutai - GO, Brazil. All rights reserved. It is distributed under the terms of the Creative Commons Attribution 4.0 International License. in the family (e.g., Mendoncia Vell. ex Vand.) (Judd et al., 2009).

Acanthaceae is divided into three subfamilies and the delimited in the features of fruits and seeds, among other factors, as pollen, corolla morphology etc. (Scotland \& Vollesen, 2000). Nelsonioideae have seeds with endosperm and fruit with no retinacula, Thunbergioideae have seeds without endosperm and no retinacula in the fruits, and Acanthoideae which comprises most of the species of the family, is characterized by the presence of retinacula in the fruit and capsules with explosive dehiscence (Scotland \&Vollesen, 2000, McDade et al., 2008).

The shape of the capsule and number of seeds vary between groups and are important features for the classification at supraspecific level (Ezcurra, 1993). The seeds can be flat, glabrous or hairy, usually flattened, often absent endosperm (Judd et al., 2009) smooth or wrinkled testa and sometimes with mucilaginous trichomes that expand when wet (Wasshausen \&Wood, 2004). Besides the fruit type and number of seeds, the mechanisms these seeds are disperse is crucial to the reproductive success of the family, and the explosive dehiscence of the fruit disperse the seeds over long distances (Kelbessa, 1990). However, this implies in herbarium specimens usually with no seeds, hampering the usage of seeds morphology for taxonomic classification. 
Considering that the capsule loculicidal is the most common type of fruit in Acanthaceae, added to the lack of seed morphology description in this type, we believe that the morphological description of such structures may be an important first step to further studies in the ecology of the family and also to improve taxonomic classification.

Recently, Ruellia L. seed morphology, and fruit characterization as well, have been the subject of studies (Azevedo \& Braz, 2018, Azevedo \& Moraes, 2019, Indriunas \& Aoyama, in press). Since Ruellia is the second largest Acanthaceae genus, comprising about 350 species, and shows taxonomic complexity, those works have important contribution for taxa research (Azevedo \& Braz, 2018, Azevedo \& Moraes, 2019).

According to Flora do Brasil (Profice et al., 2020), in Brazil occur 84 species, 40 of which are endemic, and only 3 can be found at restinga areas. Among then, Ruellia furcata (Nees) Lindau has a restrict distribution in Bahia, Espírito Santo and Rio de Janeiro States.

Thus, this study aimed to characterize the morphology of the fruits and seeds of Ruellia furcata (Nees) Lindau from São Mateus, Espírito Santo State, bringing information on the species morphology and also comparing it with other species of the genus, searching for possible variations.

\section{MATERIAL AND METHODS}

The fruits and seeds were collected in a restinga forest of Liberdade (18 44'10.52 "S 39 48'37.72" W), São Mateus, Espírito Santo State, Brazil. This forest is distributed over a sandy barrier originated in Pleistocene, being constructed at the quaternary, due to the regressive and transgressive marine process (Martin et al., 1997). The sample identification was made by experts of the Botanical Institute of São Paulo and the voucher was registered under number 442082 fall in the Herbarium "Maria Fidalgo Eneyda PK" from the Botanical Institute of São Paulo. The collection of fruits and seeds was carried out with the aid of a gauze type fabric involving a few individuals chosen at random.

Morphological characterization of fruits and seeds of Ruelliafurcata was performed in the laboratory of Plant Biology at the Universidade Federal do Espírito Santo (CEUNES). For fruits, we used 30 units randomly selected and measured in: length of the fertile portion and the basal sterile portion, total length, width, thickness, and retinacula height. For seeds we used 95 units measured in: length, width, and thickness using a caliper with unit of measure in millimeters. The observations were made through a stereoscopic microscope.

The description of fruits and seed were based on Ezcurra (1993). For the fruits, it was observed internal and external details of the pericarp related to texture, consistency, color, hairiness, shape, numbers of seeds per fruits, dehiscence and for the seeds it was observed the dimension, color, texture, consistency, shape, presence or absence of endosperm, presence or absence of trichomes.

\section{RESULTS}

The mean values of fruits and seeds are shown in Tab.1 and the ratio between the fertile and sterile fruit is equal to 2.11 .

Table 1. Dimensions of fruits and seed of Ruellia furcata (Nees) Lindau (Acanthaceae).

\begin{tabular}{|c|c|c|c|c|c|}
\hline & \multicolumn{2}{|c|}{ Dimensions (mm) } & \multirow{2}{*}{$\frac{\text { Average }}{12.29 \pm 1.25}$} & \multirow{2}{*}{$\begin{array}{l}\text { Smaller } \\
9.34\end{array}$} & \multirow{2}{*}{$\frac{\text { Greater }}{14.64}$} \\
\hline \multirow{7}{*}{ 莺 } & Length & Total & & & \\
\hline & & Basal & $3.94 \pm 0.51$ & 3.08 & 5.04 \\
\hline & & Sterile portion & & & \\
\hline & & Fertile portion & $8.35 \pm 0.94$ & 6.26 & 9.78 \\
\hline & & Retinacula & $3.82 \pm 0.49$ & 3.02 & 4.78 \\
\hline & Width & & $3.60 \pm 0.53$ & 2.52 & 4.96 \\
\hline & Thickness & & $4.51 \pm 0.78$ & 1.38 & 5.52 \\
\hline \multirow{3}{*}{ 苋 } & Length & & $3.85 \pm 0.35$ & 3.04 & 4.53 \\
\hline & Width & & $3.59 \pm 0.26$ & 3.01 & 4.1 \\
\hline & Thickness & & $0.46 \pm 0.09$ & 0.19 & 0.65 \\
\hline
\end{tabular}

The fruits are loculicidal capsule type with two valves, four retinacula, dry, green when immature, brown at maturity, hairy, elliptical shape, with four seeds and have explosive dehiscence (Figs. 1A, B, C). The seeds have no aril, are rounded, flat, biconcave, with no reserve of food, sarcotest an absent, apexobt use, rough brown staining and seed coat with a layer of mucilage hairs, hygroscopic, yellowish along the edge (Fig. 1E). In the dry seed, the hygroscopic trichomes are attached to the surface of the coat (Fig. 1D). The measures showed that the fruits present a solid long basal portion in relation to the fertile.

\section{DISCUSSION}

The ratio between the length of the sterile and fertile portions of the fruit characterized different groups, thus, the studied species most be included with in Physiruellia group, characterized by a solid long basal portion in relation to the fertile part (1/3) and a few seed per locule (3-7) (Ezcurra, 1993).

The loculidal capsule type of fruit are present in most species of the family (Judd et al., 2009). Witztum \& Schulgasser (1995), studying the mechanisms of seed expulsion in Acanthaceae, concluded that the stress state established in fruit is a result of dynamic tissue that tends to contract, but is prevented by the resistance tissue of the rostrum, resulting in the storage of elastic energy within the valves. When the stress becomes greater than the resistance of the tissue of the rostrum, beak valve explosion occurs, making the elastic energy stored in the valves in kinetic energy. 

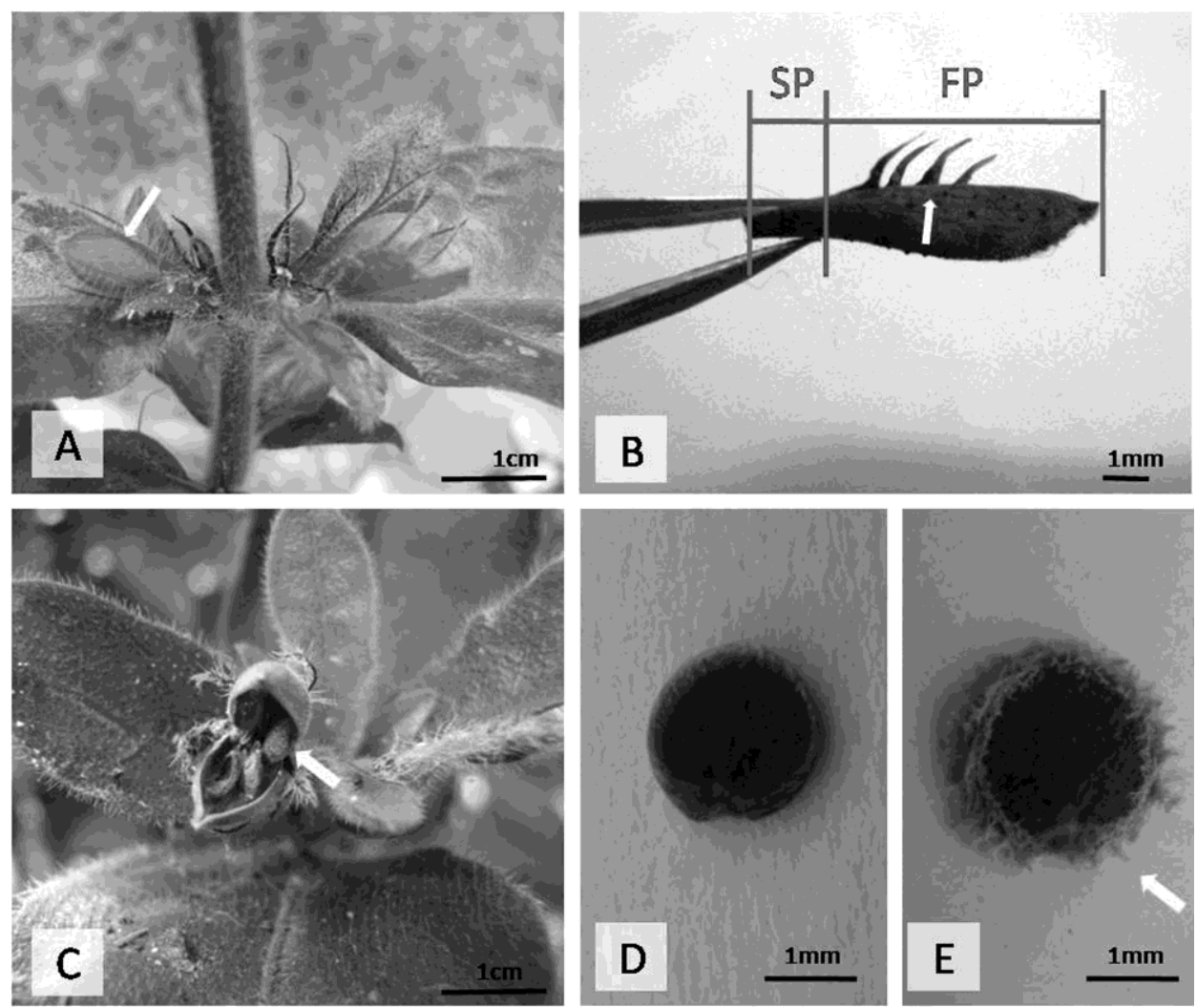

Figure. 1. (A) Morphology of the fruits of Ruellia furcata (Nees) Lindau (arrow). (B) Position of the four retinacula (arrow), indicating the basal sterile portion (PE) and the fertile portion (PF) of the fruit. (C) Aspect of the opened fruit with seeds (arrows). (D) Dry seed. (E) Seed with mucilaginous trichomes in the margin (arrow).

To ensure efficiency in the dispersion besides a great initial velocity of the seed, it is also necessary to be released at a certain angle, a process performed by the retinacula that enhance acceleration and direct the angle of expulsion of the seeds (Witztum \& Schulgasser, 1995). The type of explosive dehiscence of the capsule is also found in other genera in the family as Dicliptera Juss., Micranthus (Pers.) Eckl., BlechumP. Browne, among others (Ezcurra, 1993).

In some species of Ruellia capsules open xerochastically induced by dry environments, or hygrochastically, induced by moisture. The higrochasy and xerochasy phenomena are superimposed, in other words, it must first build up the tension in the fruit as a result of desiccation, and then the moisture at the end of the capsule, which unites the two valves, triggers the release of seeds (Witztum \& Schulgasser, 1995).

The seeds of the family may have mucilaginous trichomes that expand when wet (Wasshausen \&Wood, 2004). This feature is present in the genera Ruellia and these trichomes may spread across the surface or be restricted to the margin (Daniel \&Acosta, 2003, Greuter \& Rodriguez, 2010). According to Ezcurra (1993), many species of the group Physiruellia have trichomes restricted to the margins of the seeds, as found for the species under study.

According to Greuter \& Rodriguez (2010) the trichomes found in Ruelliinae seeds are commonly thin and numerous. In the dry seed the trichomes form a compact layer on the testa, but in contact with water these trichomes are released, keeping stucked at the seed, in the same time releasing a mucilaginous substance, which after drying will attach the seed firmly to the substrate (Greuter \& Rodriguez, 2010).

This mucilage may play an important role in the dispersion, especially for animals. Aspects such as adaptive plasticity to different environmental conditions, autogamy and dispersal by animals (ectozoochory) makes many species, good colonizers and ensure its success in dispersion over long distances (Ezcurra, 1993).

\section{CONCLUSION}

Ruellia furcata has fruits loculicidal capsule type with two valves, four retinacula, hairy, elliptical shape, with four seeds and have explosive dehiscence and seeds have no aril, are rounded, flat, biconcave, sarcotesta absent, apex obtuse, rough brown staining and seed coat with a layer of mucilage hairs, hygroscopic. In the dry seed, the hygroscopic trichomes are attached to the surface of the coat. Those features are found in other 
species of the genus. The measures showed that the fruits present a solid long basal portion in relation to the fertile with similar features to other species of the genus. The morphological features of the fruits and seeds here presented reinforces the fact that they are mainly selected by the mechanism of expulsion and facilitation of the seeds dispersal, facilitating the dispersion of this species in a variety of environmental conditions, in which they occur.

\section{ACKNOWLEDGEMENTS}

We would like to thank the Universidade Federal do Espírito Santo (CEUNES) for providing the laboratory of Plant Biology and the Instituto de Botânica de São Paulo for their assistance in performing this work.

\section{CONFLICT OF INTEREST}

The authors declare no conflict of interest.

\section{REFERENCES}

Abreu, C. R. M. \&Vieira, M. F. (2004). Os beija-flores e seus recursos florais em um fragmento florestal de Viçosa, sudeste brasileiro. Instituto de Ciências Biológicas, Universidade Federal de Minas Gerais, Minas Gerais. Lundiana, 5,129-134.

Azevedo, I. H. F. \& Braz, D. M. (2018). Seed morphology of Ruellia L. (Acanthaceae) from the Southeastern Brazilian Atlantic rain forest: Taxonomic, phylogenetic, and ecological aspects. Flora, 240, 48-57.

Azevedo, I. H. F. \& Moraes, P. L. R. de. (2019). Seed Morphology of Ruellieae Species (Acanthaceae) in Brazil and Its Taxonomic Implications. Systematic Botany, 44(3), 631-651.

Daniel, T. F. \& Acosta Castellanos, S. (2003). Flora del Bajio y de regiones adyacentes. Fasciculo 117. Família Acanthaceae. Patzcuaro, Michoacan: Instituto de Ecologia.

Daniel, T. F. \&McDade, L. A. (2014). Nelsonioideae (Lamiales: Acanthaceae): revision of genera and catalog of species. Aliso, 32(1), 1-45. https://doi.org/10.5642/aliso.20143201.02

Ezcurra, C. (1989). Ruellia sanguinea (Acanthaceae) y especies relacionadas em Argentina, Uruguay y sur de Brasil. Darwiniana. 29, 269-287.

Ezcurra, C. (1993). Systematics of Ruellia (Acanthaceae) in southern South America. Annalsofthe Missouri Botanical Garden, 80, 787845. https://doi.org/10.2307/2399931

Greuter, W. \& Rodríguez, R.R. (2010). Notes on some endemic Cuban species of Ruelliinae (Acanthaceae), on their seeds, pollen morphology and hygroscopic features. Willdenowia, 40(2), 285-304.https://doi.org/10.3372/wi.40.40210

Indriunas, A., \& Aoyama, E. M. (2020). Microescultura da testa da semente madura de Ruellia elegans Poir. (Acanthaceae). Journal of biotechnology and biodiversity, in press.

Judd, W.S., Campbell, C.S., Kellog, E.A., Stevens, P.F.\& Donoghue, M. J. (2009). Sistemática vegetal: um enfoque filogenético. 3 ed., Porto Alegre: Artmed.

Kelbessa, E. (1990). Justicia sect. Anselia (Acanthaceae). Acta Universitatis Upsaliensis: Symbolae Botanicae Upsalienses, XXIX(2), 1-96.

Lorenzi, H., \& Souza, H. M. (2008). Plantas ornamentais do Brasil: arbustivas, herbáceas e trepadeiras. Instituto Plantarum de Estudos da Flora, Nova Odessa, São Paulo.

Martin, L., Suguio, K., Domingues, J.M.L., \& Flexor, J.M. (1997). Geologia do Quaternário costeiro do Litoral Norte do Rio de Janeiro e Espírito Santo. Belo Horizonte: CPRM.

McDade, L.A., Daniel, T.F., \& Kiel, C.A. (2008). Towards a comprehensive understanding of phylogenetic relationships among lineages of Acanthaceae s.l. (Lamiales). American Journal of Botany, 95,1-17. https://doi.org/10.3732/ajb.0800096

Monteiro, M. M., \& Aoyama, E. M. (2012). Morfoanatomia foliar de Ruellia furcata (Nees) Lindau (Acanthaceae). Enciclopédia Biosfera, 8(14), 735-750.

Profice, S.R., Kameyama, C., Côrtes, A.L.A., Braz, D.M., Indriunas, A.,Vilar, T., Pessoa C., Ezcurra, C., \& Wasshausen, D.(2020).Acanthaceae In Listade Espécies da Flora do Brasil. Jardim Botânico do Rio de Janeiro. Acanthaceae in Flora do Brasil 2020 em construção. Jardim Botânico do Rio de Janeiro. Disponível em: <http://floradobrasil.jbrj.gov.br/reflora/floradobrasil/FB33 $>$. Acesso em: 29/07/2020.

Roderjan, C. V. (1983). Morfologia do estádio juvenil de 24 espécies arbóreas de uma floresta com araucária. (Dissertação de Mestrado). Universidade Federal do Paraná, Brasil.

Scotland, R.W., \&Vollesen, K. (2000). Classificationof Acanthaceae. KewBulletin, 55, 513-589. https://doi.org/10.2307/4118776

Wasshausen, D.C.\&Wood, J.R.I. (2004). Acanthaceae of Bolivia. Smithsonian Institution Contributions from the United States National Herbarium. Department of Botany. National Museum of Natural History, DC 49, 1-152.

Witztum, A. \& Schulgasser, K. (1995). The mechanics of seed expulsion in Acanthaceae. Journal of Theoretical Biology, 176, 531-542.

To cite this paper:

Monteiro, M. M., Indriunas, A., Aoyama, M. (2020). Morphological characterization of fruits and seeds of Ruellia furcata (Nees) Lindau (Acanthaceae) from Espírito Santo State, Brazil. Multi-Science Journal, 3(3), 65-68. DOI: https:// doi.org/10.33837/msj.v3i3.1265 